U.S. Department of the Interior

U.S. Geological Survey

\section{Trace Elements and Organic Compounds Associated with Riverbed Sediments in the Rio Grande/Río Bravo Basin, Mexico and Texas}

In cooperation with the Texas Natural Resource Conservation Commission

\section{Introduction}

In 1991, the Texas Natural Resource Conservation Commission (TNRCC) was mandated by the Texas Clean Rivers Act (Senate Bill 818) to assess water quality of rivers in Texas. Recent efforts to collect information for the assessment of water quality in the Rio Grande/Río Bravo Basin have involved Federal agencies on both sides of the 1,248mile U.S.-Mexico border-U.S. Environmental Protection Agency, U.S. Geological Survey (USGS), Secretaria de Desarollo Social (Secretary for Social Development, Mexico), National Water Commission of Mexico, and International Boundary and Water Commission-as well as State and local agencies in a spirit of international cooperation. Substantial efforts have been made to gather data needed to determine the quality of water and ecological status of the Rio Grande/Río Bravo, especially at sites along the border (fig. 1). The purpose of this report is to assess selected historical data of trace elements and organic compounds in riverbed sediments of the Rio Grande/Río Bravo, and of the Pecos River and the Arroyo Colorado in Texas.

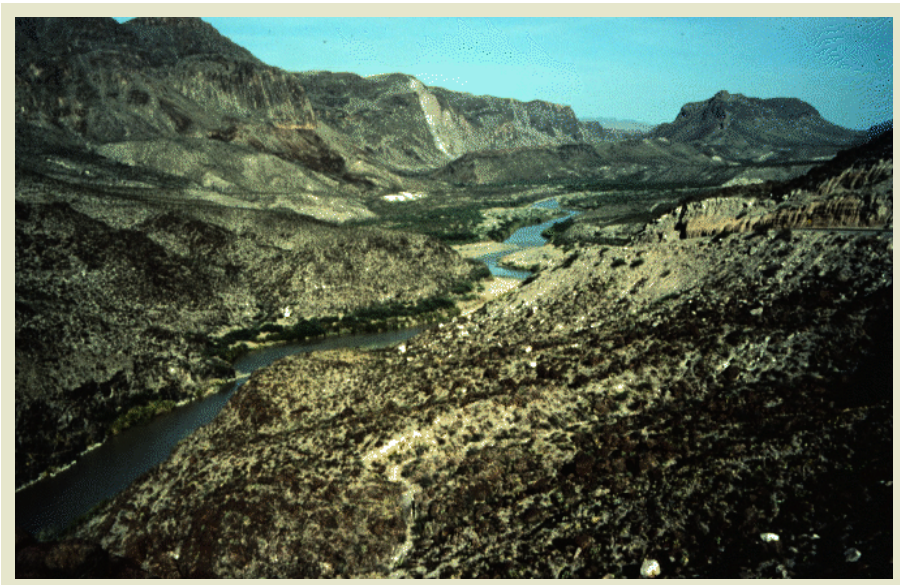

Rio Grande/Río Bravo Basin in West Texas.

\section{Why Analyze for Trace Elements and Organic Compounds in Riverbed Sediments?}

Sediments in rivers usually come from erodible materials in a watershed, primarily soils and weathering rocks. During storms these sediments wash into tributary channels and into the main channel of a river. As flow velocity and turbulence decrease following a storm, suspended particles settle, accumulating along the riverbed near the sediment sources in slow-moving waters. Reservoirs on a river system further decrease flow velocity and turbulence and accumulate the sediment transported by runoff from upstream watersheds. In the river channel where sediments accumulate, the top layer of sediment represents recent transport and deposition of erodible materials from tributary watersheds. Some transport of sediment will continue under base-flow conditions, but the transported sediment typically is finer grained; and less sediment is transported than under stormflow conditions.

In a natural setting, the sources of trace elements in riverbed sediments are geologic materials and atmospheric deposition. In the Rio Grande/Río Bravo Basin in Texas, the primary geologic materials are sedimentary rocks of Cretaceous, Tertiary, and Quaternary age (fig. 2) consisting principally of limestone and dolostone with sand, sandstone,

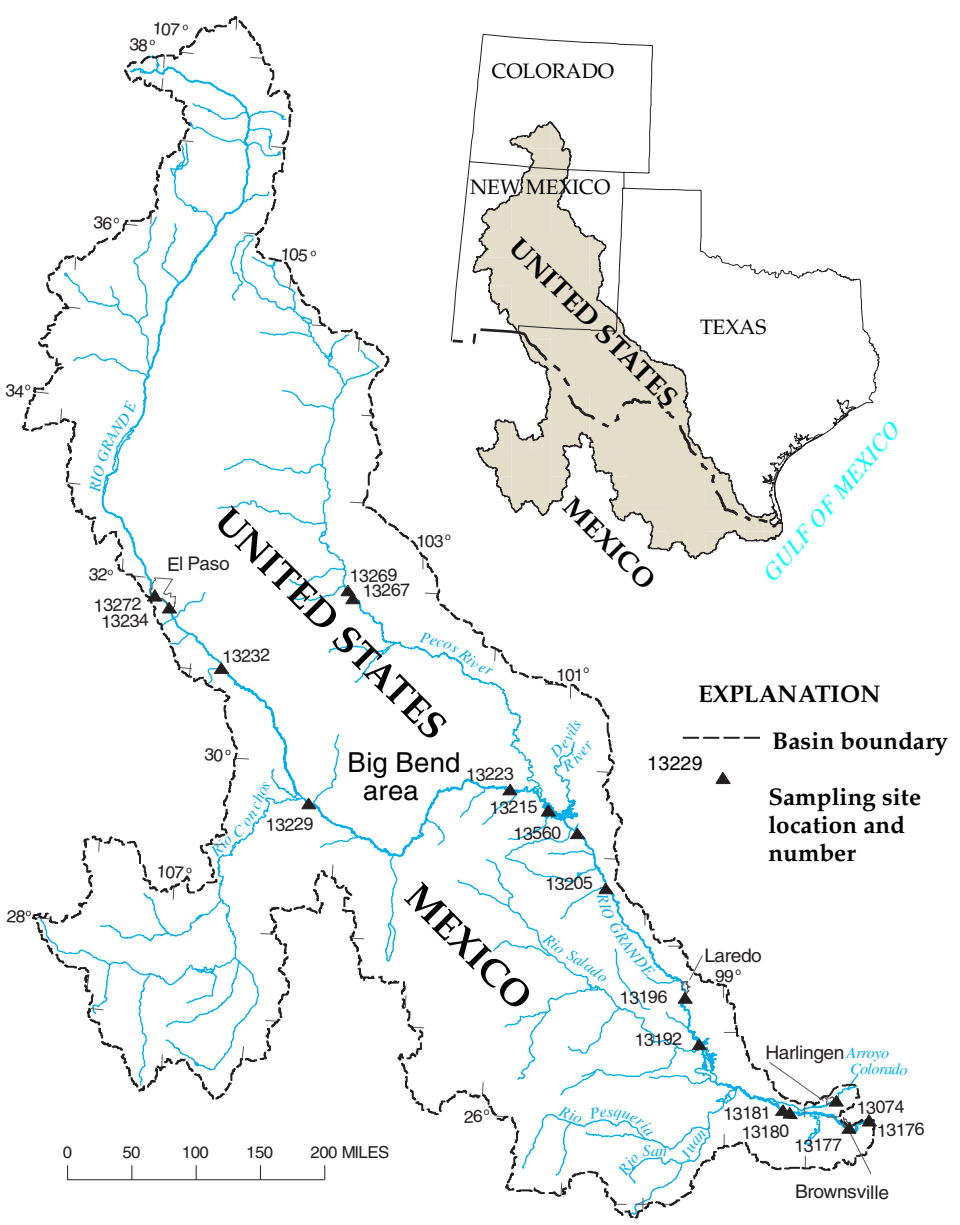

Figure 1. Rio Grande/Río Bravo Basin, United States and Mexico, showing major streams and riverbed-sediment sampling sites.

clay, and shale locally. Exposed bedrock and atmospheric deposition from volcanos are natural sources of trace elements in riverbed sediments. Concentrations of trace elements from these natural sources should remain relatively constant over decades and even for centuries.

Human activities can cause release of trace elements and synthetic organic compounds to the atmosphere or to stormwater runoff in a watershed. Many of these constituents are more concentrated in sediments than in the water column. Mining and disposal of tailings, followed by weathering of tailings, and stormwater transport of trace element-laden sediment from mined areas, can produce pulses of high concentrations of some trace elements in riverbed sediments. Cinnabar (mercury ore) was mined in the Big Bend area of Texas from the late 1800 s to as recently as the late 1960 s. The occurrence of concentrations of synthetic organic compounds in riverbed sediments is a more recent phenomenon resulting from development and other human activities and cannot be related to geologic sources.

Many trace elements and organic compounds are toxic to humans and aquatic life. These constituents could originate from point or nonpoint sources in a watershed, or might be deposited in the watershed from atmospheric sources outside the watershed. Under some chemical 


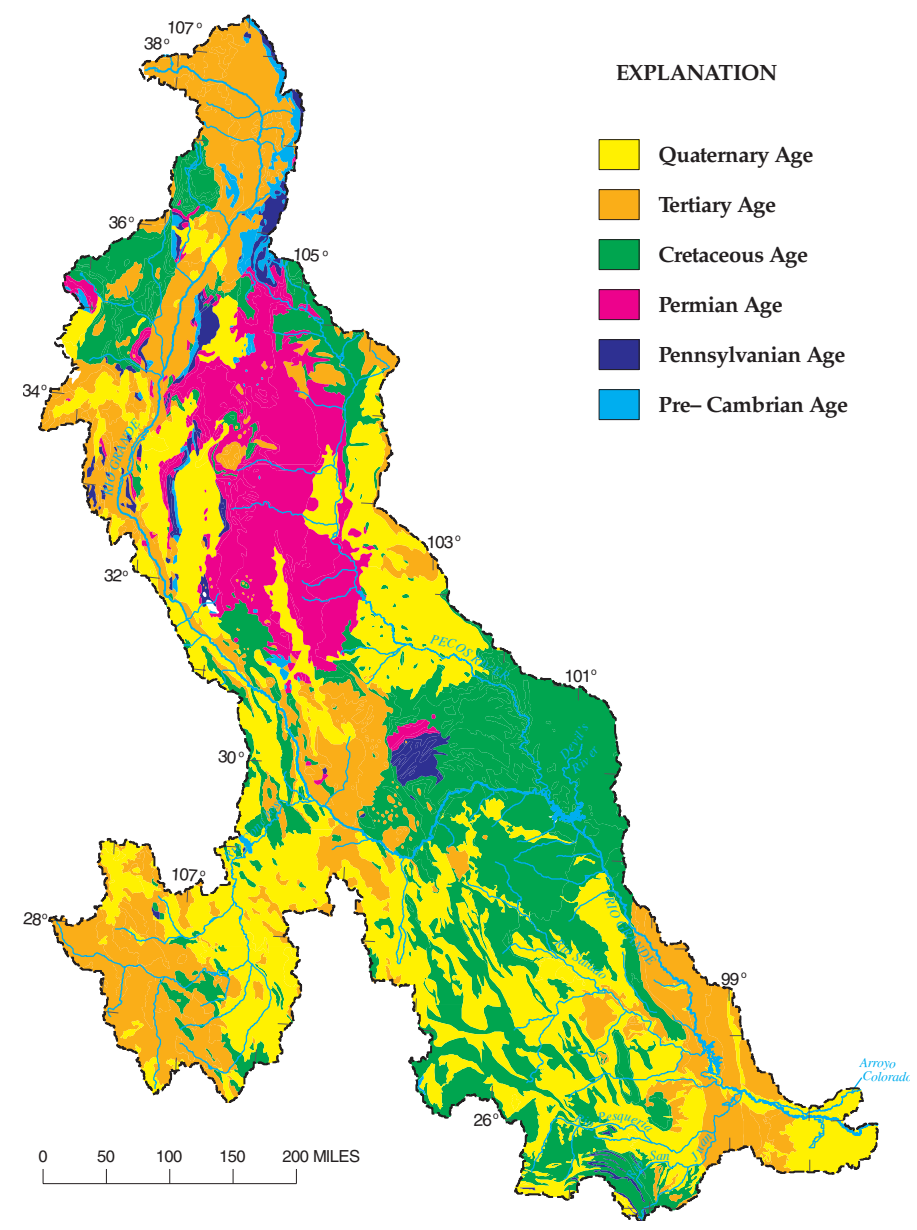

Figure 2. Surface geology of the Rio Grande/Río Bravo Basin.

conditions, many trace elements will attach or "sorb" to available inorganic materials such as clays or mineral coatings rather than remaining dissolved in the water. Similarly, many organic compounds (especially high molecular-weight chlorinated hydrocarbon compounds) attach to particles of natural organic matter or to inorganic particles coated with organic matter rather than remaining dissolved in the water. Sediments laden with various trace elements and organic compounds from a source watershed are transported in runoff and streamflow and deposited on the river bottom. Screening levels for trace elements and organic compounds detected in sediments of Texas waterbodies have been established by the TNRCC. The screening level for each substance is the 85 th-percentile concentration ( 85 percent of the concentrations are less than this value) computed from the 1983-92 TNRCC statewide Surface Water Quality Monitoring data base of waterbody sediment analyses (Steve Twidwell, Texas Natural Resource Conservation Commission, written commun., 1997).

\section{What Historical Trace Element and Organic Compound Data Are Available and How Can They Be Interpreted?}

Samples of riverbed sediments of the Rio Grande/Río Bravo Basin for this study were collected and analyzed for trace elements and organic compounds from the early 1970s through 1994 . Chemical data for riverbed sediments from the international watershed gathered during investigations in the United States are accessible through the STORET water-quality data base of the U.S. Environmental Protection Agency. Samples analyzed for trace element concentrations are available for about 50 sites in Texas; samples analyzed for concentrations of organic compounds are available for as many as 59 sites.
Sampling has been sporadic. Only a few sites in the entire basin have been sampled annually and have relatively complete analyses. On the basis of data availability, 19 sites were selected for study. All 19 of the sites were selected to show the ranges in concentration of 4 trace elements (arsenic, lead, mercury, and selenium); 17 of the 19 sites were selected for analysis of spatial and temporal trends in concentrations of 12 trace elements. Sufficient data are available to show the ranges in concentration of 8 organic compounds detected at 16 sites; organic compound data are insufficient for analysis of temporal trends, with the exceptions of bis(2-ethylhexyl)phthalate, chlordane, and PCBs at one site on the Arroyo Colorado. Collectively among all sites with organic compound analyses, 140 compounds were analyzed.

The ranges in concentration and summary statistics (25th percentile, median, and 75th percentile) of trace elements and organic compounds are shown by boxplots grouped by site from El Paso to the Gulf of Mexico. Spatial trends in concentrations of trace elements and organic compounds - that is, significant increases or decreases in concentrations along the Rio Grande/Río Bravo from El Paso to the Gulf of Mexicowere determined by a statistical test (Kendall's tau (Helsel and Hirsch, 1992, p. 212)) for the significance (at the 90-percent confidence level) of the correlation between concentrations and downstream order of 17 sampling sites. Temporal trends in concentrations - that is, significant increases or decreases in concentrations with time at each of the 17 Rio Grande/Río Bravo sites-were similarly determined on the basis of the significance (at the 90-percent confidence level) of the correlation between concentrations and chronological order of sampling. No trend analyses were done on sites with fewer than seven analyses.

\section{What Do the Historical Trace Element and Organic Compound Data Show?}

\section{Trace Elements}

Historical median arsenic concentrations exceed the TNRCC screening level in the Big Bend area downstream of the Río Conchos (site 13229) and at Amistad International Reservoir (site 13215) (fig. 3A). Arsenic concentrations in sediments are greatest from the Río Conchos to Amistad International Reservoir. Arsenic concentrations in sediments show an increasing trend in downstream direction (table 1). Arsenic concentrations increase with time at the three most upstream sites in and near El Paso (sites 13272, 13234, and 13232), which historically have relatively low arsenic concentrations. Although median arsenic concentrations are relatively high at site 13229 , concentrations with time at the site show a decreasing trend. Concentrations in Falcon International Reservoir also show a decreasing trend (site 13192).

Historical median lead concentrations are well below the screening level at all sites (fig. 3B). Lead concentrations in riverbed sediments show a decreasing trend in downstream direction (table 1). Lead concentrations increase with time upstream of the Big Bend area (site 13232) and at Laredo (site 13196) and either decrease or have no discernible trend at the other sampling sites.

Historical median mercury concentrations are below the screening level for all sites (fig. 3C). However, recent (about 1994) TNRCC analyses for mercury in riverbed sediments show concentrations above the screening level at 14 of the 19 Rio Grande/Río Bravo sites (13272, 13234, 13232, 13229, 13223, 13269, 13267, 13215, 13560, 13196, $13192,13180,13074$, and 13177). Mercury concentrations show an increasing trend in downstream direction (table 1). Mercury concentrations increase with time at the 2 Pecos River sites and at 7 sites on the Rio Grande/Río Bravo (sites 13272, 13223, 13215, 13205, 13196, 13180 , and 13177). Of the 12 trace elements analyzed for trends, only mercury has no decreasing trend in concentrations with time at any of the 17 sites.

Historical median selenium concentrations exceed the screening level at the 2 Pecos River sites and the 2 Rio Grande/Río Bravo sites downstream of Amistad International Reservoir and upstream of Laredo 


\section{EXPLANATION}

- Outlier data value more than 3 times the interquartile range outside the interquartile range

Outlier data value 1.5 to 3.0 times the interquartile range outside the interquartile range

Data value less than or equal to 1.5 times the interquartile range outside the interquartile range

75 th percentile

Median (50th percentile) Interquartile Note: For stations with less than six samples, only

(50th percentile) range maximum, minimum, and median are shown.

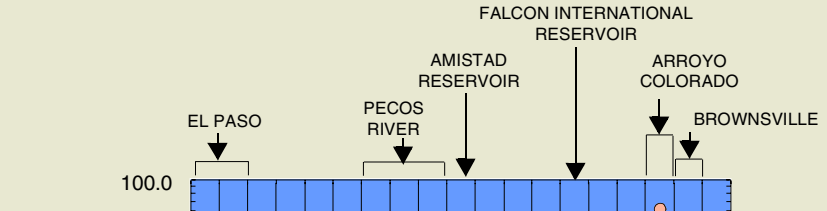

25th percentile

(19) Number of samples

Texas Natural Resource Conservation Commission screening level

\section{A. Arsenic ${ }^{1}$}

- Naturally occurring in minerals and volcanic gases

- Released to environment by coal burning and smelting

- Historically used in pesticides

- Toxic to animals and humans; carcinogenic and mutagenic

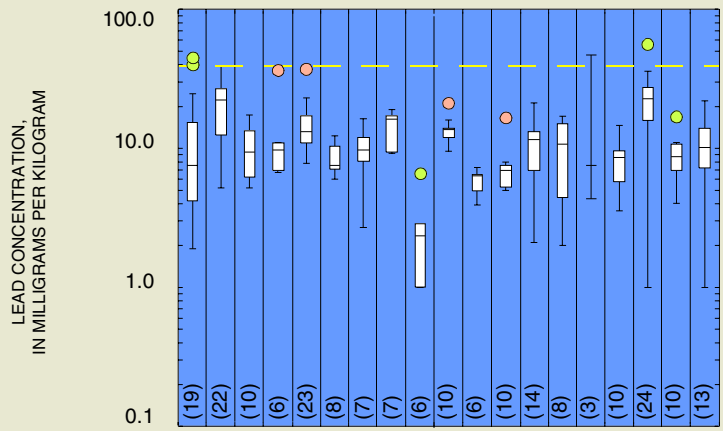

B. Lead ${ }^{1}$

- Naturally occurring in minerals

- Released to environment by coal burning, smelting, and combustion of leaded fuels

- A constituent of paints, ceramic glazes, and plumbing materials

- Toxic to animals and humans

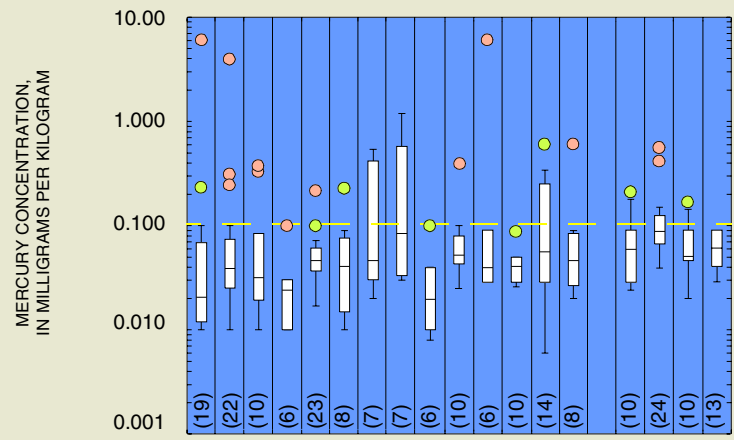

C. Mercury ${ }^{1}$

- Naturally occurring in minerals (for example cinnabar, mined extensively in Terlingua, Tex.)

- Released to environment by coal burning, industrial uses (chemicals and plastics), and mineral extraction

- Toxic to animals and humans

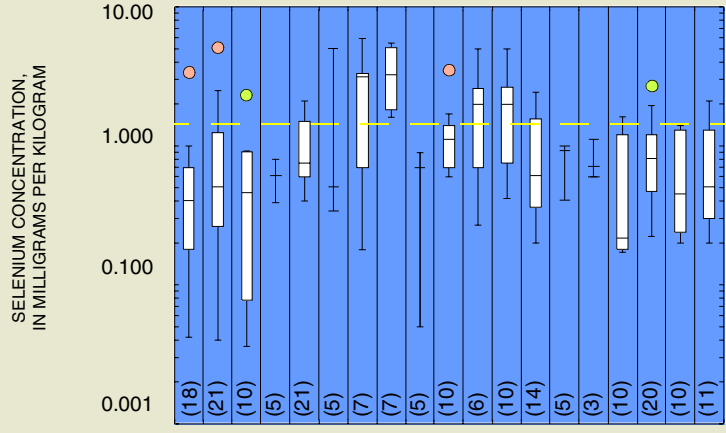

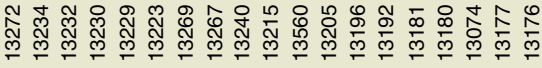

STATION ID

\section{Selenium ${ }^{1}$}

- Naturally occurring especially in the western U.S. desert soils and shales

- Manufacture of glass, rubber, solar cells, and semiconductors

- Released from soils by plant uptake or irrigation

- Toxic to animals and humans, especially waterfowl

${ }^{1}$ From Hem, 1985.

Figure 3. Concentrations of selected trace elements in riverbed sediments of the Rio Grande/Río Bravo, Pecos River, and Arroyo Colorado. 
Table 1. Spatial and temporal trends of trace elements and selected organic compounds in riverbed sediments in the Rio Grande/Río Bravo Basin

[Number of detections shown if insufficient for temporal trend analysis; -- indicates no detections]

\section{Increasing trend}

Decreasing trend

No trend

Insufficient data
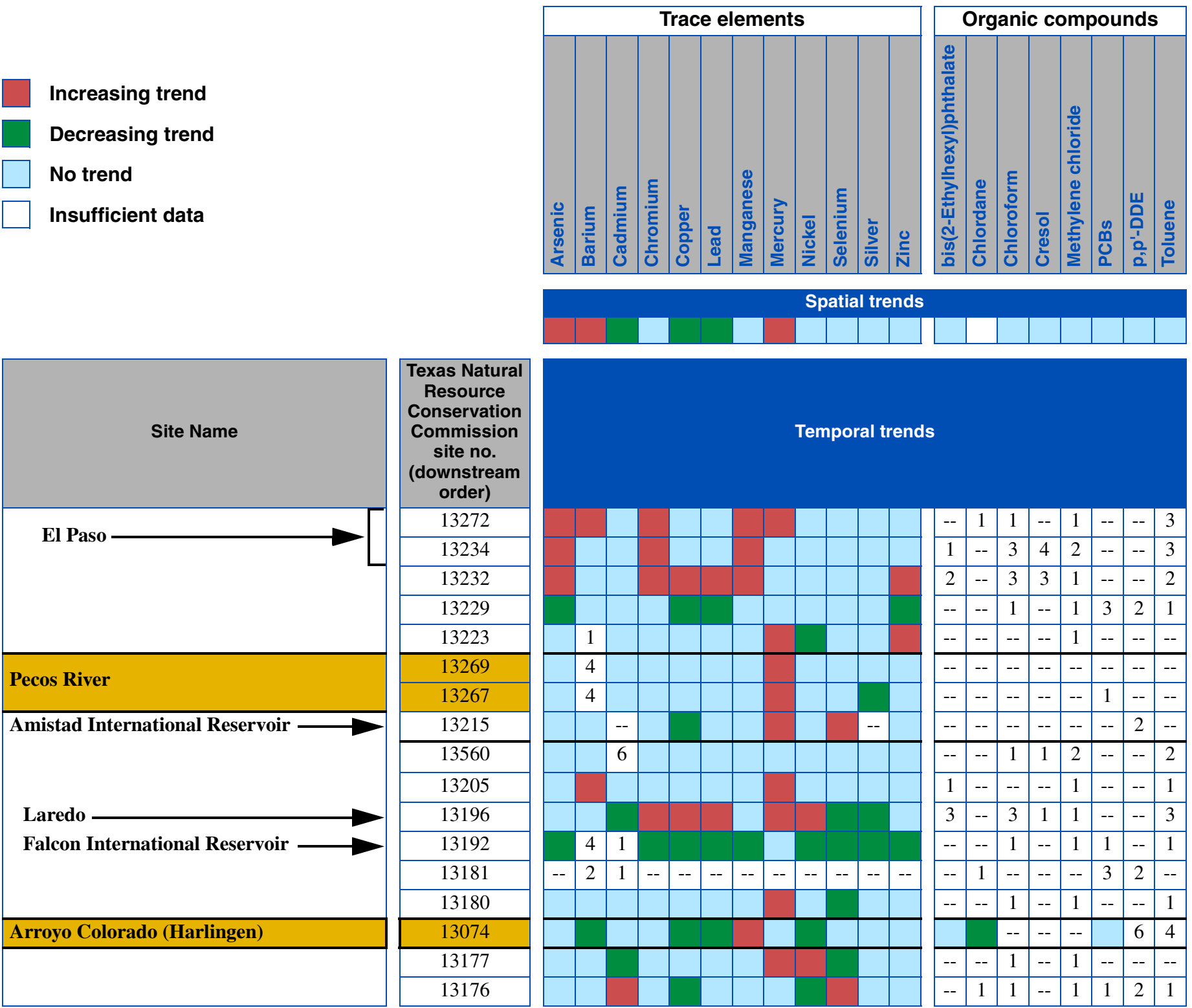

\begin{tabular}{|c|}
\hline $\begin{array}{c}\text { Texas Natural } \\
\text { Resource } \\
\text { Conservation } \\
\text { Commission } \\
\text { site no. } \\
\text { (downstream } \\
\text { order) }\end{array}$ \\
\hline 13272 \\
\hline 13234 \\
\hline 13232 \\
\hline 13229 \\
\hline 13223 \\
\hline 13269 \\
\hline 13267 \\
\hline 13215 \\
\hline 13560 \\
\hline 13205 \\
\hline 13196 \\
\hline 13192 \\
\hline 13181 \\
\hline 13180 \\
\hline 13074 \\
\hline 13177 \\
\hline 13176 \\
\hline
\end{tabular}

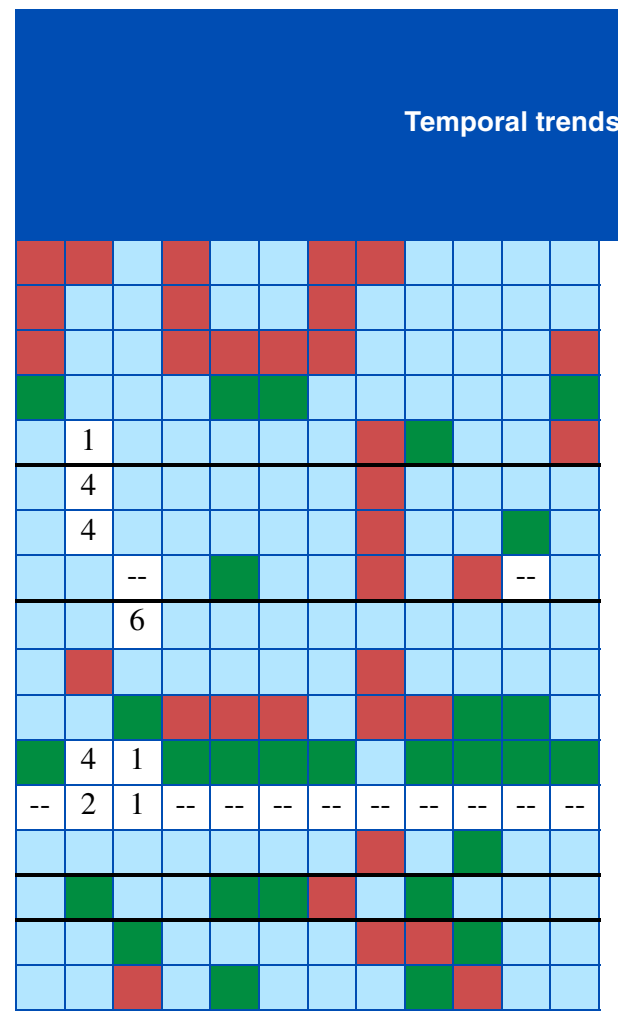

\begin{tabular}{|c|c|c|c|c|c|c|c|}
\hline-- & 1 & 1 & -- & 1 & -- & -- & 3 \\
\hline 1 & -- & 3 & 4 & 2 & -- & -- & 3 \\
\hline 2 & -- & 3 & 3 & 1 & -- & -- & 2 \\
\hline-- & -- & 1 & -- & 1 & 3 & 2 & 1 \\
\hline-- & -- & -- & -- & 1 & -- & -- & -- \\
\hline-- & -- & -- & -- & -- & -- & -- & -- \\
\hline-- & -- & -- & -- & -- & 1 & -- & -- \\
\hline-- & -- & -- & -- & -- & -- & 2 & -- \\
\hline-- & -- & 1 & 1 & 2 & -- & -- & 2 \\
\hline 1 & -- & -- & -- & 1 & -- & -- & 1 \\
\hline 3 & -- & 3 & 1 & 1 & -- & -- & 3 \\
\hline-- & -- & 1 & -- & 1 & 1 & -- & 1 \\
\hline-- & 1 & -- & -- & -- & 3 & 2 & -- \\
\hline-- & -- & 1 & -- & 1 & -- & -- & 1 \\
\hline & & -- & -- & -- & & 6 & 4 \\
\hline-- & -- & 1 & -- & 1 & -- & -- & -- \\
\hline-- & 1 & 1 & -- & 1 & 1 & 2 & 1 \\
\hline
\end{tabular}

(sites 13560 and 13205) (fig. 3D). Although intermediate increases and decreases can be observed in the selenium data, there is no downstream trend for the reach from El Paso to the Gulf of Mexico. Selenium concentrations show increasing trends with time at two sites, Amistad International Reservoir (site 13215) and at the mouth of the Rio Grande/Río Bravo (site 13176); other sites have decreasing trends or no trend.

The remaining eight trace elements analyzed for trends are near or below screening levels at most sites except for copper at the two El Paso sites (13272 and 13234) and the Arroyo Colorado site (13074) near Harlingen; and manganese at the El Paso, Laredo (13196), and Arroyo Colorado sites. Analyses show increasing trends in downstream direction in barium concentrations; and decreasing trends in downstream direction in cadmium and copper concentrations. Of all trace elements analyzed for, the largest number of trace elements with increasing temporal trends are at sites in and near El Paso (13272, 13234, and 13232) and at Laredo (13196); and the largest number of trace elements with decreasing temporal trends are at Falcon International Reservoir (13192).

\section{Organic Compounds}

Of the 140 organic compounds for which available samples were analyzed, 16 compounds were detected at least once (table 2). Of the 16 compounds detected at least once, 8 compounds (bis(2ethylhexyl)phthalate, chlordane, chloroform, cresol, methylene chloride, $\mathrm{PCBs}$, p,p'-DDE, and toluene) were found at 16 of the 17 sites (fig. 4). Of the 8 organic compounds, 7 compounds (bis(2-ethylhexyl)phthalate, chloroform, cresol, methylene chloride, PCBs, p,p'DDE, and toluene) have sufficient data to test for trends in downstream direction. None of the seven compounds show a downstream trend in concentration (table 1).

Bis(2-ethylhexyl)phthalate, chlordane, and PCBs at the site near Harlingen on the Arroyo Colorado (13074) are the only organic compounds with sufficient data to test for temporal trends. Chlordane concentrations show a decreasing trend with time at the site; bis(2ethylhexyl)phthalate and PCBs show no trends with time. 
Table 2. Number of sites sampled, detections, and nondetections of organic compounds in the Rio Grande/Río Bravo Basin

\begin{tabular}{|c|c|c|c|c|c|c|c|}
\hline Organic compound & No. of sites & Detections & Nondetections & Organic compound & No. of sites & Detections & Nondetections \\
\hline Acenaphthylene & 25 & 0 & 99 & 2-Chlorophenol & 24 & 0 & 99 \\
\hline Acrylonitrile & 25 & 0 & 86 & 2-Nitrophenol & 24 & 0 & 99 \\
\hline Anthracene & 21 & 0 & 94 & di (n-octyl) Phthalate & 24 & 0 & 99 \\
\hline Benzo(b)fluoranthene & 25 & 0 & 100 & 2,4-Dichlorophenol & 24 & 1 & 96 \\
\hline Benzene & 25 & 0 & 96 & 2,4,-Dimethylphenol & 24 & 0 & 98 \\
\hline Benzo(k)fluoranthene & 25 & 0 & 100 & 2,4-Dinitrotoluene & 24 & 0 & 99 \\
\hline Benzo(a)pyrene & 25 & 0 & 99 & 2,4-Dinitrophenol & 24 & 0 & 99 \\
\hline beta Benzene hexachloride & 25 & 0 & 6 & 2,4,6-Trichlorophenol & 24 & 0 & 97 \\
\hline bis(Chloromethyl)ether & 5 & 0 & 6 & 2,6-Dinitrotoluene & 24 & 0 & 98 \\
\hline delta Benzene hexachloride & 6 & 0 & 6 & 3,3-Dichlorobenzidine & 24 & 0 & 99 \\
\hline bis(2-Chloroethyl)ether & 6 & 0 & 99 & 4-Bromophenyl phenyl ether & 24 & 0 & 97 \\
\hline bis(2-Chloroethoxy)methane & 25 & 0 & 100 & 4-Chlorophenyl phenyl ether & 24 & 0 & 99 \\
\hline bis(2-Chloroisopropyl)ether & 25 & 0 & 100 & 4-Nitrophenol & 24 & 0 & 99 \\
\hline Bromoform & 25 & 0 & 96 & Phenol $\left(\mathrm{C}_{6} \mathrm{H}_{5} \mathrm{OH}\right)$ & 24 & 0 & 99 \\
\hline n-butyl Benzyl phthalate & 25 & 0 & 100 & trans-1,3-Dichloropropene & 23 & 0 & 92 \\
\hline Carbon tetrachloride & 25 & 0 & 97 & cis-1,3-Dichloropropene & 23 & 0 & 93 \\
\hline Chlorobenzene & 25 & 2 & 94 & PCP (pentachlorophenol) & 45 & 0 & 176 \\
\hline Chlorodibromomethane & 25 & 0 & 96 & Chlordane nonachlor, trans isomer & 28 & 0 & 63 \\
\hline Chloroethane & 25 & 1 & 94 & alpha Benzene hexachloride & 46 & 0 & 161 \\
\hline Chloroform & 25 & 16 & 90 & bis(2-Ethylhexyl)phthalate & 40 & 15 & 142 \\
\hline Chrysene & 25 & 0 & 100 & di (n-butyl) Phthalate & 39 & 4 & 150 \\
\hline Dichlorobromomethane & 24 & 0 & 93 & Pentachlorobenzene & 20 & 0 & 63 \\
\hline Dichlorodifluoromethane & 6 & 0 & 6 & Benzidine & 23 & 0 & 92 \\
\hline Diethyl phthalate & 25 & 0 & 100 & Polychlorinated naphthalenes & 4 & 0 & 6 \\
\hline Dimethyl phthalate & 25 & 0 & 96 & p,p'-DDT & 32 & 1 & 66 \\
\hline 1,2-Diphenylhydrazine & 24 & 0 & 91 & o,p'-DDT & 28 & 0 & 63 \\
\hline Endosulfan sulfate & 28 & 0 & 119 & $p, p^{\prime}-D D D$ & 32 & 0 & 68 \\
\hline Endosulfan, beta & 6 & 0 & 6 & o,p'-DDD & 28 & 0 & 62 \\
\hline Endosulfan, alpha & 6 & 0 & 6 & p,p'-DDE & 32 & 24 & 44 \\
\hline Endrin aldehyde & 6 & 0 & 6 & $o, p^{\prime}-D D E$ & 28 & 0 & 63 \\
\hline Ethylbenzene & 25 & 1 & 95 & Chlordane & 59 & 23 & 271 \\
\hline Fluoranthene & 25 & 0 & 100 & Endosulfan & 22 & 0 & 94 \\
\hline Fluorene & 25 & 0 & 99 & Heptachlor epoxide & 60 & 0 & 294 \\
\hline Hexachlorocyclopentadiene & 25 & 0 & 99 & Methoxychlor & 60 & 0 & 299 \\
\hline Hexachloroethane & 25 & 0 & 100 & PCB-1221 & 25 & 0 & 90 \\
\hline Indeno (1,2,3-cd) pyrene & 25 & 0 & 100 & PCB-1232 & 25 & 0 & 90 \\
\hline Isophorone & 25 & 0 & 100 & PCB-1242 & 25 & 0 & 90 \\
\hline Methylene chloride & 25 & 18 & 78 & PCB-1248 & 25 & 0 & 90 \\
\hline N-Nitrosodi-n-propylamine & 25 & 0 & 100 & Arochlor 1254 & 25 & 0 & 90 \\
\hline N-Nitrosodiphenylamine & 25 & 0 & 100 & PCB-1260 & 25 & 0 & 90 \\
\hline Methyl bromide & 6 & 0 & 6 & PCB-1016 & 25 & 0 & 90 \\
\hline Methyl chloride & 6 & 0 & 6 & PCBs & $\mathbf{5 5}$ & 29 & 197 \\
\hline N-Nitrosodimethylamine & 24 & 0 & 92 & Guthion & 23 & 0 & 78 \\
\hline Naphthalene & 25 & 0 & 100 & Methyl parathion & 42 & 0 & 173 \\
\hline Nitrobenzene & 25 & 0 & 100 & Atrazine & 5 & 0 & 5 \\
\hline Parachlorometa cresol & 22 & 0 & 75 & Hexachlorobenzene & 45 & 0 & 171 \\
\hline Phenanthrene & 21 & 0 & 94 & Hexachlorobutadiene & 24 & 0 & 99 \\
\hline Pyrene dry & 25 & 0 & 100 & $2,4-D$ & 45 & 0 & 178 \\
\hline Tetrachloroethylene & 24 & 2 & 92 & $2,4,5-\mathrm{T}$ & 42 & 0 & 173 \\
\hline Toluene & 25 & 26 & 81 & Silvex & 51 & 0 & 200 \\
\hline Trichloroethylene & 24 & 0 & 92 & Lindane & 60 & 0 & 304 \\
\hline Vinyl chloride & 25 & 0 & 95 & Xylene & 24 & 0 & 95 \\
\hline 1,1-Dichloroethane & 24 & 0 & 95 & Hexachlorophene & 19 & 0 & 56 \\
\hline Trichlorofluoromethane & 6 & 0 & 6 & N-Nitrosodi-n-butylamine & 19 & 0 & 56 \\
\hline 1,1-Dichloroethylene & 23 & 0 & 87 & Styrene & 5 & 0 & 5 \\
\hline 1,1,1-Trichloroethane & 24 & 0 & 94 & 2,4,5-Trichlorophenol & 20 & 0 & 66 \\
\hline 1,1,2-Trichloroethane & 24 & 0 & 94 & Mirex & 23 & 0 & 68 \\
\hline 1,1,2,2-Tetrachloroethane & 24 & 1 & 92 & Dursban & 23 & 0 & 80 \\
\hline Benzo(g,h,i)perylene 1,1,2-benzoperylene & 24 & 0 & 99 & Sevin & 15 & 0 & 27 \\
\hline Benzo(a)anthracene 1,2-benzanthracene & 24 & 0 & 99 & Anthracene and phenanthrene & 5 & 0 & 5 \\
\hline 1,2-Dichloroethane & 24 & 0 & 95 & Demeton & 15 & 0 & 37 \\
\hline 1,2-Dichlorobenzene & 24 & 0 & 99 & Bromomethane & 21 & 0 & 90 \\
\hline 1,2-Dichloropropane & 24 & 0 & 94 & 1,2-Dibromoethane & 21 & 0 & 77 \\
\hline trans-1,2-Dichloroethene & 22 & 0 & 88 & Cresol & 20 & 9 & 73 \\
\hline 1,2,4-Trichlorobenzene & 24 & 0 & 96 & N-Nitrosodiethylamine & 19 & 0 & 56 \\
\hline 1,2,5,6-Dibenzanthracene & 24 & 0 & 99 & Pyridine & 19 & 0 & 58 \\
\hline 1,3-Dichlorobenzene & 24 & 0 & 99 & 1,2,4,5-Tetrachlorobenzene & 19 & 0 & 56 \\
\hline 1,4-Dichlorobenzene & 24 & 0 & 99 & Chloromethane & 21 & 0 & 89 \\
\hline 2-Chloroethyl vinyl ether & 21 & 0 & 89 & Chlorfenvinphos & 5 & 0 & 5 \\
\hline 2-Chloronaphthalene & 24 & 0 & 99 & Chlorothalonil & 5 & 0 & 5 \\
\hline
\end{tabular}

Detections 


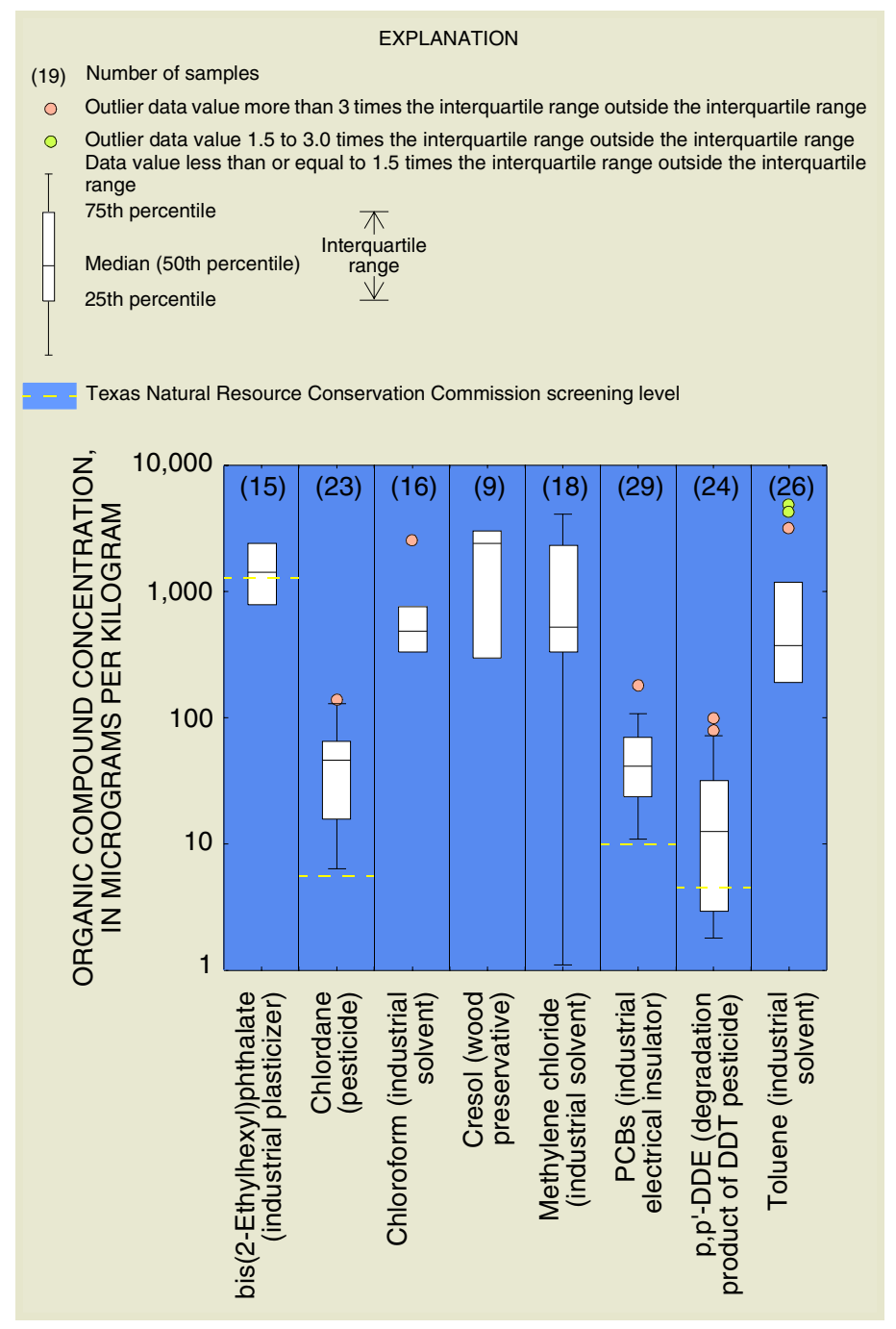

Figure 4. Concentrations of selected organic compounds in riverbed sediments of the Rio Grande/Río Bravo and Arroyo Colorado.

\section{What Do These Results Indicate?}

Based on the data for riverbed sediments in the Rio Grande/Río Bravo Basin, trace elements are more commonly detected than organic compounds. Geologic sources of trace elements that could account for background concentrations of trace elements cannot be readily identified because the amounts from sources associated with human activities in the basin are unknown. Increasing temporal trends in more trace elements in the vicinity of El Paso and Laredo than in other reaches of the rivers for which samples are available indicate that sources of trace elements possibly are related to human activities within the respective watersheds. Although historical median mercury concentrations are below the TNRCC screening level, recent sample concentrations above the screening level, increasing temporal trends at more than one-half the sites, and no decreasing temporal trends at any site could indicate that either mercury sources are widespread in the basin or the source of mercury is non point, possibly atmospheric. Regional-scale increases in mercury concentrations in the northeastern and north-central United States during the past 100 years have been documented using lakesediment cores and attributed to atmospheric pollution (Swain and others, 1992).

Organic compounds are not prevalent in riverbed sediments, but the presence of those detected probably warrants continued monitoring.
The generally greater occurrence of organic compounds near El Paso, Laredo, and Harlingen indicates the likelihood of urban sources.

\section{Selected References}

Helsel, D.R., and Hirsch, R.M., 1992, Studies in environmental science 49-Statistical methods in water resources: Amsterdam, Elsevier, $522 \mathrm{p}$.

Hem, J.D., 1985, Study and interpretation of the chemical characteristics of natural water, (3d ed.): U.S. Geological Survey Water-Supply Paper 2254, $263 \mathrm{p}$.

International Boundary and Water Commission, United States and Mexico, 1994, Binational study regarding the presence of toxic substances in the Rio Grande/Río Bravo and its tributaries along the boundary portion between the United States and Mexico, final report: Dallas, U.S. Environmental Protection Agency, 245 p.

Swain, E.B., Engstrom, D.R., Brigham, M.E., Henning, T.A., and Brezonik, R.C., 1992, Increasing rates of atmospheric mercury deposition in midcontinental North America: Science, v. 257, p. 784-787.

Van Metre, P.C., Mahler, B.J., and Calender, Edward, 1997, Water-quality trends in the Rio Grande/Río Bravo Basin using sediment cores from reservoirs: U.S. Geological Survey Fact Sheet FS-221-96, 8 p.

Watershed Management Division, Texas Natural Resource Conservation Commission, 1994, Regional assessment of water quality in the Rio Grande Basin: Austin, Tex., Texas Natural Resource Conservation Commission Publication AS-34, 377 p.

-R.W. Lee and J.T. Wilson

For more information please contact:

District Chief

U.S. Geological Survey

8011 Cameron Road

Austin, TX 78754-3898

Phone: (512) 873-3000

FAX: (512) 873-3090

World Wide Web: http://txwww.cr.usgs.gov

Any use of trade, product, or firm names is for descriptive purposes only and does not imply endorsement by the U.S. Government. 